\title{
REVIEW
}

\section{The effect of GH and IGF1 on linear growth and skeletal development and their modulation by SOCS proteins}

\author{
S F Ahmed and C Farquharson' \\ Developmental Endocrinology Research Group, Division of Developmental Medicine, Department of Child Health, Royal Hospital For Sick Children, University \\ of Glasgow, Yorkhill, Glasgow G3 8SJ, UK \\ ${ }^{1}$ Bone Biology Group, Division of Developmental Biology, The Roslin Institute and Royal (Dick) School of Veterinary Studies, University of Edinburgh, Roslin, \\ Edinburgh EH25 9PS, UK \\ (Correspondence should be addressed to S F Ahmed; Email: s.f.ahmed@clinmed.gla.ac.uk)
}

\begin{abstract}
Circulating signalling proteins have often been divided into hormones and cytokines, but it is increasingly being recognised that these substances have a number of common characteristics and mechanisms of action. This is clearly illustrated by the suppressor of cytokine signalling (SOCS) proteins which are increasingly seen as a central component of the regulation of the action of hormones and cytokines that signal through the cytokine receptor complex. The SOCS protein family is probably more extensive than currently
\end{abstract}

recognised; its members may have differential tissue expression and their potency for suppressing cytokine signalling may vary. Recent knockout and transgenic studies in mice have highlighted the role that these proteins play in growth and skeletal development as well as in inflammation. Chronic inflammation is associated with altered growth and skeletal development, and it is possible that SOCS proteins may have an important role to play in mediating these effects. Journal of Endocrinology (2010) 206, 249-259

\section{Introduction}

Linear growth and skeletal development are tightly regulated processses that are highly dependent on $\mathrm{GH}$ signalling and action. Clinical studies have shown that growth and skeletal development are impaired during periods of uncontrolled chronic inflammation which is often associated with altered systemic and local cytokine milieu. The mechanisms by which these inflammatory cytokines modulate linear growth and skeletal development are poorly understood, but an involvement of members of the suppressor of cytokine signalling (SOCS) family has been proposed. This review will first describe SOCS proteins and the effects of the GH/insulin-like growth factor 1 (IGF1) axis on linear growth and skeletal development before describing the evidence that highlights the role of SOCS proteins in controlling this axis as well as in skeletal development.

\section{Cytokine signalling}

Cellular responses to cytokine stimulation depend on the type of cytokine and the nature of the target cell, and include immune function, inflammation, and cell proliferation and differentiation. The interaction between a cytokine and its receptor induces receptor dimerisation or oligomerisation, which results in the juxtaposition of a group of proteins that are members of the Janus kinase (JAK) family of protein tyrosine kinases - JAK1, JAK2, JAK3 and TYK2 (Ihle \& Kerr 1995). These can cross-phosphorylate, causing enzymatic activation of the cytokine receptor. GH, prolactin and leptin are just some of the ligands that signal through these same receptors and along with other cytokines have their own specific preferential JAKs. A key target of JAK activity is the cytoplasmic domain of the cytokine receptor, which becomes tyrosine phosphorylated at multiple residues, creating docking sites for signalling proteins containing Src homology 2 (SH2) or phosphotyrosine-binding domains. It is likely that some downstream signalling pathways are common to all cytokine receptors and some are specific for individual cytokine receptors (Leaman et al. 1996). The association between signalling proteins and cytokine receptors serves to initiate multiple signalling pathways, such as those regulated by Ras sarcoma proteins (RAS), phosphatidylinositol 3-kinase (PI3K) and the signal transducers and activators of transcription (STATs). Together, these pathways culminate in the regulation of gene expression in the nucleus, resulting in an appropriate cellular response to the cytokine. The STAT family, consisting of at least seven transcription factors, plays a critical role in regulating physiological responses to cytokine stimulation. Members of 
the STAT family bind tyrosine-phosphorylated cytokine receptors through their SH2 domains. Once bound to the receptor, STATs are phosphorylated by JAKs, following which they dissociate from the receptor and form homo- or heterodimers. STAT dimers then translocate to the nucleus, where they interact with specific DNA elements in the promoters of cytokine-responsive target genes and thus regulate transcription (Darnell 1997). The transcriptional activity of STATs may depend on a number of factors including its interaction with other proteins within the cell. For instance, STAT5 transcriptional activity is increased by formation of a complex with the glucocorticoid or mineralocorticoid receptor, while it is reduced by formation of a complex with the oestrogen receptor (Stoecklin et al. 1999).

\section{SOCS proteins}

Suppression of signalling through the activated cytokine receptor can occur by receptor degradation through the ubiquitin/proteosome pathway or by dephosphorylation of tyrosines within JAK or the receptor. The SOCS proteins are an important group of proteins that are generated in response to cytokines and can also bind through their SH2 domains to phosphorylated tyrosines within the cytokine receptor-JAK complex, and inhibit further cytokine receptor activation (Hilton 1999). These proteins may also promote proteosomal degradation of the JAKs (Zhang et al. 1999). The SOCS family contains at least eight members: SOCS1-7 and the cytokine inducible SH2-containing protein (CIS). Although SOCS1, 2, 3 and CIS are well characterised, little is known about the function and mechanisms of action of SOCS4-7. Structurally, SOCS proteins possess a poorly conserved amino-terminal domain of variable length, a central SH2 domain, as well as a highly conserved amino acid C-terminal domain, named the SOCS box (Fig. 1). Although the basal levels of SOCS proteins are generally low, their expression levels have been shown to be markedly induced by numerous cytokines, growth factors and hormones, such as interleukin 1 (IL1), IL2, IL3, IL4, IL6, IL9, IL10, IL11, interferon $\alpha$ (IFN- $\alpha$ ), IFN- $\gamma$, insulin, ciliary neurotrophic factor, granulocyte colony-stimulating factor, leukaemia inhibitory factor, $\mathrm{GH}$, angiotensin II, cardiotrophin, oestrogen, prolactin and thyrotrophin. The transcriptional regulation of SOCS proteins appears to be mediated, at least in part, by the STAT signalling pathway. Indeed, the promoter region of SOCS genes, such as the murine Socs3, may have specific sequences for STAT binding (Auernhammer et al. 1999) or for other hormones such as oestrogen (Leong et al. 2004). Accordingly, cells transfected with a dominant negative mutant of STAT3 failed to induce SOCS expression following IL6 stimulation. Furthermore, SOCS proteins, particularly, murine SOCS2, 6 and 7, may be able to regulate the degradation of other members of their family (Piessevaux et al. 2006). Finally, the SOCS family of proteins may be larger than the eight that have been hitherto described. There are up
SOCS protein homologies

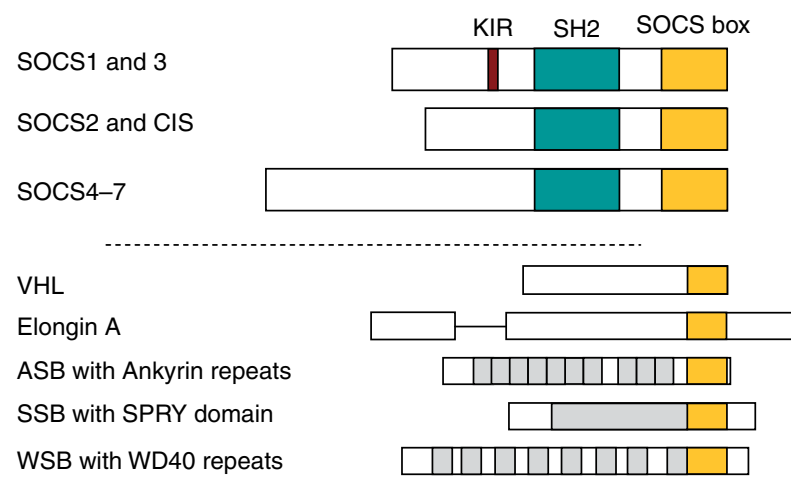

Figure 1 Diagram representing the structure of SOCS proteins. Eight proteins that belong to the SOCS family of proteins are shown in the upper panel. They are characterised by the presence of an Src homology $2(\mathrm{SH} 2)$ central domain and the SOCS box domain at the C-terminus. A small domain called kinase inhibitory region (KIR), only found in SOCS1 and SOCS3, is shown as a small box at the $\mathrm{N}$-terminal region. SOCS proteins can interact with phosphorylated tyrosines through their $\mathrm{SH} 2$ domain and with Elongin $\mathrm{BC}$ through their SOCS box domain. Some other proteins containing a SOCS box domain but lacking a $\mathrm{SH} 2$ domain are shown in the lower panel.

to 20 proteins with similar SOCS motifs, and there are also other proteins such as caveolin 1, which can also suppress cytokine signalling by inhibiting the kinase activity of JAK family members (Jasmin et al. 2006).

\section{The GH/IGF1 axis}

GH and IGF1 are important regulators of longitudinal growth. GH is a single-chain peptide of 191 amino acids. The synthesis and release of GH from the anterior pituitary gland are promoted by GHRH, and inhibited by somatostatin but regulated by a range of central and peripheral signals (Goldenberg \& Barkan 2007). IGF1, which is secreted by the liver under GH control, inhibits GH secretion directly in somatotrophs and indirectly by stimulating the release of somatostatin (Goldenberg \& Barkan 2007). GH circulates bind to a GH-binding protein, which is the extracellular domain of the GH receptor (GHR; Bougnères \& Goffin 2007). The function of the GH-binding protein is incompletely understood, although it may modulate the activity of GH either by prolonging its half-life or by reducing its availability to the GHR.

In the human, the GHR is highly expressed in the liver, adipose tissue, heart, kidneys, intestine, lung, pancreas, cartilage and skeletal muscle where it induces the synthesis of IGF1 (Ballesteros et al. 2000). However, systemic IGF1 which is synthesised primarily in the liver circulates as part of a 150-kDa complex formed by one molecule each of IGF1, IGF-binding protein (IGFBP)-3, the predominant circulating-binding protein, or IGFBP-5, and the acid labile subunit 
(ALS). There are six IGFBPs, and IGFBP-1, $-2,-4$ and -6 also can bind IGF1 in the circulation and peripheral tissues but do not form part of the ternary complex (Holly \& Perks 2006). IGFBPs are in concentrations in excess of IGF1. Consequently, IGF1 circulates mostly bind to the complex, and $<1 \%$ of total serum IGF1 circulates as a free hormone. The 150-kDa ternary complex stabilises IGF1, prolonging its circulating half-life and regulating its availability to target tissues. Consequently, the ternary complex plays an important role in determining the endocrine function of IGF1. Although, in excess, IGFBPs inhibit IGF1 action, the triple inactivation of IGFBP-3, -4 and -5 demonstrated that IGFBPs are necessary to maintain appropriate levels of systemic IGF1 and adequate postnatal growth (Ning et al. 2006). ALS is synthesised in the liver under the control of GH and circulates in excess over the other components of the complex, so that it plays a critical role in the storage and release of IGF1. IGF2 shares biochemical and biological properties with IGF1; it is important in skeletal development, but its function in the adult skeleton is not proven. IGF2 is synthesised by skeletal cells, but its synthesis is not GH dependent. The IGF2/mannose-6-phosphate receptor does not play a major role in IGF signal transduction and is responsible for clearing IGF2, regulating its levels, during foetal development (Blackburn et al. 1997).

\section{The GH/IGF1 axis and bone}

Bone is a dynamic connective tissue that undergoes a continuous process of resorption and renewal. The principal cells that mediate this process include the osteoprogenitor cells that contribute to maintaining the osteoblast population, the osteoblasts that sythesise the bone matrix, the osteocytes that influence bone structure and response to mechanical load and the osteoclasts that promote bone resorption.

Osteoblast maturation and function requires a spectrum of signalling proteins including morphogens, hormones, growth factors, cytokines, matrix proteins and transcription factors that act in a temporal-specific manner (Aubin et al. 2006). Through the PI3K pathway, IGF1 may reduce osteoblast apoptosis and promote osteoblastogenesis by stabilising $\beta$-catenin, enhancing Wnt-dependent activity (Playford et al. 2000, Krishnan et al. 2006). This effect, associated with modest mitogenic properties, causes an increase in the number of osteoblasts, and an increase in osteoblastic function and bone formation (Canalis 1980). The effect of IGF1 on bone resorption is less clear than on bone formation. IGF1 induces RANK-L synthesis (and as a consequence osteoclastogenesis) and enhances osteoclast function (Mochizuki et al. 1992). IGF1 induces vascular endothelial growth factor (VEGF) expression in skeletal cells, and VEGF may serve to couple angiogenesis with endochondral bone formation and with osteoblastic differentiation and function (Akeno et al. 2002). Transgenic mice expressing IGF1 under the control of the osteoblast-specific osteocalcin promoter exhibit increases in trabecular bone secondary to an increase in bone formation (Zhao et al. 2000). Igf1 null mutants exhibit reduced cortical bone but not trabecular bone, possibly due to a compensatory increase in GH secretion or due to a decrease in trabecular bone resorption (Liu et al. 1993). Mice carrying mutations of the GHRH receptor (lit/lit mouse) or the GHR have no GH secretion or action, and consequently low levels of systemic IGF1 (Beamer \& Eicher 1976, Sims et al. 2000). These mutants display osteopenia and reduced cortical bone, but display normal trabecular bone. The contribution of systemic IGF1 to cortical bone integrity is confirmed in mice carrying a liver-specific igf1 deletion singly or in combination with an als deletion. These mice, which display reductions in serum IGF1, have decreased cortical bone (Yakar et al. 2009). These observations confirm the contribution of systemic IGF1 to cortical bone integrity and to a lesser extent to trabecular bone integrity. In contrast, the locally produced skeletal IGF1 plays a more significant role in trabecular bone integrity. This is demonstrated in transgenic mice expressing IGF1 in osteoblasts and in conditional igf1 receptor null mice, which display decreased osteoblast number and function, causing reduced bone formation and reduced trabecular bone volume (Zhao et al. 2000, Zhang et al. 2002). Therefore, systemic IGF1 maintains cortical bone structure, whereas skeletal IGF1 serves to maintain trabecular bone structure. The function of IGF1 in skeletal homeostasis is confirmed in irs 1 or irs 2 null mutants, which also exhibit osteopenia (Gazzerro \& Canalis 2006). At a local level, although GH is not a major inducer of IGF1 in osteoblasts, parathyroid hormone (PTH) and other inducers of cAMP increase IGF1 expression in osteoblasts, and IGF1 may, therefore, mediate some of the actions of PTH in bone in vitro and in vivo (Canalis et al. 1989). On the other hand, glucocorticoids decrease IGF1 transcription in osteoblasts, and their inhibitory effects on the function of the mature osteoblast may be partly explained by reduced IGF1 levels in the bone microenvironment (Delany et al. 2001).

For osteoclastogenesis, two cytokines, RANKL and MCSF play a very important role. The discovery of RANKL, a member of the tumor necrosis factor (TNF) superfamily, was preceded by the identification of its naturally occurring inhibitor, osteoprotegerin (OPG) which is produced by osteoblasts. Optimal osteoclast function depends on the creation of a suitable microenvironment that facilitates bone resorption, and this requires an acidic milieu, the presence of a lysosomal enzyme cathepsin $\mathrm{K}$ and the presence of integrins that facilitate the physical intimacy between the osteoclast and the bone matrix. In osteoclastogenesis, growth factors, such as transforming growth factor $\beta$ (TGF- $\beta$ ), which is the most abundant cytokine in the bone matrix, play an important role in maintaining and enhancing the responsiveness of osteoclast precursors to RANKL (Fuller et al. 2000). Osteoclasts are reported to express GH and IGF1 receptors in the mammal (Zhang et al. 1992, Fiorelli et al. 1996, Hou et al. 1997), and in vivo or in vitro exposure to recombinant $\mathrm{GH}$ is associated with an increase in markers of bone resorption (Kassem et al. 1994) and increased osteoclast activity (Guicheux et al. 1998). 
GH and IGFBP-5 exposure can increase osteoclast activation and can stimulate osteoclastogenesis; it is possible that the former effect may be dependent on the presence of osteoblasts, but promotion of osteoclast differentiation from haematopoietic blast cells seems to be an osteoblast-independent effect (Nishiyama et al. 1996, Kanatani et al. 2000). Furthermore, the $\mathrm{GH}$ induced-osteoclast differentiation seems to be independent of IGF1, whereas the activation of osteoclast is dependent on IGF1 (Kanatani et al. 2000). Thus, unlike bone formation, where the stimulatory effects of GH seem to be via IGF1, GH seems to have a more profound independent stimulatory effect on bone resorption. Pro-inflammatory cytokines such as TNF- $\alpha$, IL1 $\beta$ and IL6 can promote osteoclastogenesis, and $\mathrm{GH}$ and IGF1 can stimulate production of these cytokines in osteoblasts (Slootweg et al. 1992, Swolin \& Ohlsson 1996) and in T-cells (Renier et al. 1996, Uronen-hansson et al. 2003). In vivo and in vitro studies suggest that GH and IGF1 may also influence osteoclast activity by altering the RANKL/OPG balance, but there is a lack of clarity about the direction and magnitude of this effect (Ueland 2005).

\section{The GH/IGF1 axis and the growth plate}

The original somatomedin hypothesis proposes that $\mathrm{GH}$ stimulates growth at the epiphysis by systemically derived liver IGF1 (Salmon \& Daughday 1957, Daughaday et al. 1972). The somatomedin hypothesis has been questioned as direct effects of $\mathrm{GH}$ on chondrocytes in vivo and in vitro have been reported (Isaksson et al. 1982, Madsen et al. 1983, Isgaard et al. 1986, Schlechter et al. 1986). Although such direct effects have not been observed by others (Burch et al. 1985, Makower et al. 1989), an alternative dual effector theory of $\mathrm{GH}$ action has been proposed (Green et al. 1985). This involves GH acting on germinal zone precursors of the growth plate to stimulate the differentiation of chondrocytes and then amplify local IGF1 synthesis, which, in turn, induces the clonal expansion of chondrocyte columns and hypertrophy in an autocrine/ paracrine manner (Isaksson et al. 1982, Green et al. 1985, Zezulak \& Green 1986). While concentration of the GHR within the germinal chondrocytes of the growth plate is consistent with the dual effector theory (Barnard et al. 1988), recent in situ hybridisation studies and immunohistochemical investigations using more specific GHR antibodies have indicated a broader distribution of the GHR within the growth plate suggesting additional roles for $\mathrm{GH}$ such as the regulation of chondrocyte proliferation, differentiation and hypertrophy (Lupu et al. 2001, Gevers et al. 2002). Interestingly, this study by Gevers et al. also indicated that the chondrocytes of the growth plate expressed GH-binding protein where it may prolong the half-life of $\mathrm{GH}$ in vivo or alternatively it may compete with the GHR for binding to $\mathrm{GH}$ and protect chondrocytes from continuous $\mathrm{GH}$ exposure. In addition to GH, IGF1 has also been shown to stimulate the proliferation of germinal zone chondrocytes, and therefore a role for systemic or local IGF1 in initiating chondrocyte events in the germinal zone of the growth plate cannot be excluded (Hunziker et al. 1994, Reinecke et al. 2000).

Further studies using conditional liver Igf1 knockout mice have also challenged the classical somatomedin hypothesis (Sjögren et al. 1999, Yakar et al. 1999). Both the studies reported a significant reduction in circulating IGF1 but not in bodyweights of the transgenic mice suggesting that while liverderived IGF1 is the main determinant of circulating IGF1 levels, it is not as important for postnatal growth as locally derived IGF1. These observations have, however, been questioned by others (Lupu et al. 2001, Stratikopoulos et al. 2008) who have suggested that the endocrine ablation of liver IGF1 only occurred after the critical postweaning growth spurt. Also liver IGF1 production was achieved in mice lacking Igf1 gene expression in all other tissues demonstrating that under these conditions, endocrine IGF1 plays a very significant role in mouse growth as its action contributes 30\% of adult body size and sustains postnatal development (Stratikopoulos et al. 2008).

The relative contributions of GH and IGF1 to pre- and postnatal bone growth have been examined through growth analysis of various transgenic mouse lines. $\mathrm{GH}$ deficiency results in impaired growth, and the growth of ghr null mice is retarded from $\sim 2$ weeks after birth (Lupu et al. 2001). In contrast, IGF1 deficiency retards both pre- and postnatal growth, and igf $1 r$ null mice, while exhibiting a more severe growth deficiency, die shortly after birth (Baker et al. 1993, Liu et al. 1993, Lupu et al. 2001). In this context, prenatally, IGF1 signalling is considered to be GH independent, whereas postnatally, IGF1 is partly or fully GH dependent with phosphorylation of STAT5b having an intermediary role (Herrington et al. 2000, Woelfle et al. 2003, Klammt et al. 2008). Under specific conditions, both $\mathrm{GH}$ and IGF1 can promote skeletal growth. Mice overexpressing GH have increased growth, but this is only observed at 3 weeks postnatally, despite high circulating GH levels at birth. This accelerated growth coincides with a delayed induction of IGF1 expression strongly suggesting that IGF1 is directly involved in mediating the GH signal (Mathews et al. 1988a). Chronic overexpression of IGF1 does not, however, accelerate skeletal growth, whereas iff1 transgenic GH-deficient mice display normal linear growth (Mathews et al. 1988b, Behringer et al. 1990). This latter observation (Behringer et al. 1990) suggests that IGF1 can mediate GH function in regulating growth. Also, mutant mice lacking IGF1 exhibit increased growth after IGF1 administration but are unresponsive to $\mathrm{GH}$ which may indicate that $\mathrm{GH}$ itself makes a smaller contribution to growth (Won \& Powell-Braxton 1998, Lupu et al. 2001). However, if all growthpromoting $\mathrm{GH}$ actions are mediated by IGF1, the expectation would be that the phenotype of $g h r$ and igf 1 null mice would be indistinguishable from double $g h r / i g f 1 r$ mutants. This has been shown not to be the case. Both ghr and igf1 null mice show reduced tibial growth that is more severe in double $\mathrm{ghr} / \mathrm{igf1r}$ mutants, and it is likely therefore that GH and IGF1 have both independent and common functions (Lupu et al. 2001, Wu et al. 2009). The independent functions of GH and IGF1 on the chondrocytes of the growth plate may, however, predominate. In comparison with the control mice, the growth deficits of the 
tibia in the double ghr/igf1r null mice are almost identical to the sum of growth deficit observed in the single ghr and igf1 mutant tibia. The contributing overlapping function has been estimated not to exceed 5\% (Lupu et al. 2001). All contributions considering the growth-promoting role of $\mathrm{GH}$ are well accepted, but the relative contributions to the growth of the direct or indirect effects of $\mathrm{GH}$ have still to be precisely determined.

The actions of IGF1, whether produced locally or systemically, are via the IGF1 receptor (IGF1R) expressed on the cell surface of the chondrocytes of the growth plate. The type-2 IGF1R is expressed equally throughout all maturational zones of the growth plate, whereas the type-1 receptor is more highly expressed by proliferating chondrocytes (Trippel et al. 1986, Parker et al. 2007). These data are consistent with the concept that IGF1 has regulatory actions on all chondrocytes of the growth plate. The IGF1 signalling pathway has a central function in modulating endochondral bone growth and regulates a number of key chondrocyte physiological processes such as chondrocyte proliferation, matrix synthesis, differentiation, hypertrophy and survival (Lupu et al. 2001, van der Eerden et al. 2003, Wang et al. 2004, Nilsson et al. 2005). Some dispute, however, exists concerning the major physiological drivers on IGF1enhanced bone growth. Chondrocyte numbers and proliferation rates are reported to be normal (Wang et al. 1999) or decreased (Lupu et al. 2001) in igf1 null mice, whereas the size of the hypertrophic chondrocytes are smaller in the igf1 mutant mice (Wang et al. 1999). The direct effects of IGF1 on bone growth have been investigated in cultured rodent metatarsals maintained in culture. Under these highly controlled conditions, IGF1 increased chondrocyte proliferation, hypertrophic cell size and linear growth (Scheven and Hamilton 1991, Mushtaq et al. 2004). One important outstanding question yet to be fully clarified is the cellular source of the IGF1 (GH dependent or independent) that controls linear bone growth. Contrasting data exist on the presence (Nilsson et al. 1990, Reinecke et al. 2000) or absence (Shinar et al. 1993, Wang et al. 1995) of IGF1 mRNA in the chondrocytes of the growth plate which may result from limitations of the methodologies employed. Recently, a combination of growth plate microdissection and quantitative PCR has revealed that IGF1 mRNA levels are very low in rat chondrocytes of the growth plate suggesting that the biological importance of this source of IGF1 may be negligible (Parker et al. 2007). Interestingly, these authors suggest that the source of IGF1 interacting with its chondrocyte receptor may be derived from the plasma or surrounding perichondrium and/or bone (Parker et al. 2007).

\section{The SOCS proteins and their effect on growth}

It is well recognised that GH/IGF1 signalling is modulated by CIS and SOCS1-3, but surprisingly, apart from studies reporting the role of SOCS2 in bone growth, little information exists on the effects of the other SOCS protein in regulating linear growth. Recent genome wide association studies have identified SOCS2 as one of 20 loci that influence human adult height (Weedon et al. 2008) This section of the review is limited to relevant data on SOCS1-3. The effect of these SOCS proteins on GH signalling is summarised in Fig. 2.

\section{SOCS1}

Analysis of socs 1 null mice has shown that this protein is indispensable for normal postnatal development. At birth, socs1-deficient mice are indistinguishable from their normal littermates, but within 10 days the socs 1 null mice exhibit stunted growth and die within the first 3 weeks of life. The smaller body weight of socs1-deficient mice was associated with an abnormal femoral marrow cell count, and cytological analysis revealed a consistent deficit of lymphocytes in this population (Starr et al. 1998). The observed growth retardation is likely to be a pathological response to uncontrolled IFN- $\gamma$ signalling observed in socs 1 null mice as treatment of socs 1 null mice with neutralising anti-IFN- $\gamma$ antibody resulted in a healthy phenotype and no growth retardation at 3 weeks of age (Alexander et al. 1999). Almost identical data were obtained in double $\operatorname{socs} 1^{-/-} /$ifn- $\gamma^{-/-}$

\section{SOCS proteins and their effect on GH signalling}

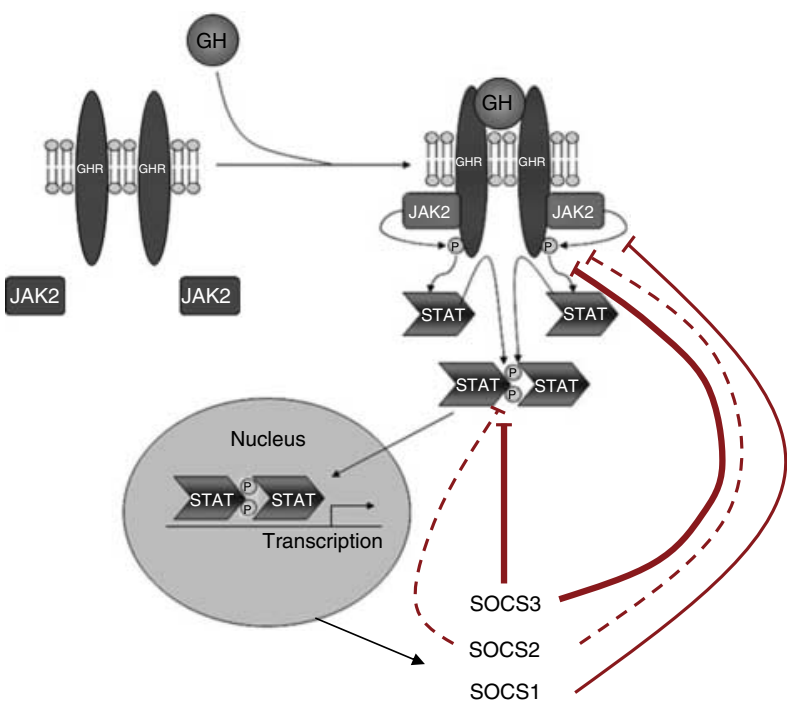

Figure 2 Inhibition of $\mathrm{GH}$ signal transduction by SOCS molecules. SOCS1, SOCS2 and SOCS3 can each inhibit signalling downstream of GHR activation; however, they do so by different mechanisms. SOCS1 binds to JAK and inhibits its ability to phosphorylate the receptor, whereas SOCS3 and SOCS2 bind to phosphorylated tyrosines that might also be STAT5-binding sites, such that SOCS2 might block STAT5 binding and thus inhibit the phosphorylation, dimerisation and transcriptional activation of STAT5. In addition, the SOCS proteins may promote proteasomal degradation of their targets. SOCS proteins, particularly, SOCS2 and SOCS3 have different levels of potency, and the final biological effect may depend on the relative concentration of the two proteins. The strength of the red lines reflects the respective potency of the inhibitory effect of SOCS1-3. Adapted from Pass et al. (2009). 
mice where the authors reported no pathology and normal body growth at 3 weeks of age (Alexander et al. 1999). It is unreported whether socs 1 null mice have elevated GH signalling, but this would be expected as inhibition of GH signalling by SOCS1 is complete (Adams et al. 1998, Hansen et al. 1999). Although an increased growth phenotype as observed in the socs 2 null mice (see below) would be expected in the socs 1 null mice, this has not been reported in socs $1^{-/-} / \mathrm{ifn} n \gamma^{-1-}$ mice maintained for up to 6 months of age (Alexander et al. 1999).

\section{SOCS2}

The phenotype of socs 2 null mice is notable due to its increase in linear bone growth and body mass where there is a proportionate augmentation of most visceral organs (Metcalf et al. 2000, Macrae et al. 2009). SOCS2 deficiency results in a $40 \%$ increase in body weight of 6-week-old male mice and a $27 \%$ increase in the body weight of 7 -week-old female mice (MacRae et al. 2009). Body length in male and female socs2deficient mice is also greater as is the length of the long bones of the fore and hind limbs (Metcalf et al. 2000, Lorentzon et al. 2005, Macrae et al. 2009). The increased longitudinal bone growth observed in socs2 null mice (Metcalf et al. 2000, Lorentzon et al. 2005, MacRae et al. 2009) is consistent with increased signalling through the GH/IGF1 axis and indicates that SOCS2 protein has a functional role in the chondrocytes of the growth plate dynamics. Nevertheless, initial histological analyses failed to record any obvious abnormalities of the epiphyseal growth plate of the tibia and femur (Metcalf $e t$ al. 2000). A fuller histomorphometric analysis, however, revealed that socs 2 null mice had wider growth plates with significantly wider proliferative and hypertrophic zones (MacRae et al. 2009). SOCS2 gene and protein are expressed preferentially by proliferating the chondrocytes of the growth plate suggesting that the increased bone growth and observed structural differences within the growth plate observed in socs 2 null mice are direct consequences of altered SOCS2 (MacRae et al. 2009). Also, based on observations on other cell types, it is possible that SOCS2 may be linked to the transition from the proliferative to the differentiated chondrocyte phenotype (Goldshmit et al. 2004, Wang et al. 2004, Ouyang et al. 2006). The effect of SOCS2 deficiency on chondrocyte proliferation, apoptosis and matrix synthesis has yet to be determined.

Enhanced growth of socs 2 null mice is not observed until 3-4 weeks of age (Metcalf et al. 2000, Macrae et al. 2009), and this is consistent with the concept that SOCS2 interacts with $\mathrm{GH}$ to negatively regulate $\mathrm{GH}$ function. Inhibition of growth in GH-deficient mice is not observed until $\sim 14$ days after birth, and peak GH activity occurs between postnatal days 20 and 40 (Lupu et al. 2001, Wang et al. 2004). Additionally, the increased growth of socs 2 null mice is not observed when mutant mice are mated with either mice lacking the STAT5b gene or those with a point mutation in the Ghrhr lit/lit mice (Greenhalgh et al. 2002, 2005). Furthermore, administration of GH to socs $2^{-/}$, Ghrhr lit/lit mice caused an increase of growth to a size indistinguishable from socs 2 null mice (Greenhalgh et al. 2005).
These observations provide further proof that the socs $2^{-1-}$ overgrowth phenotype is dependent on aberrant $\mathrm{GH}$ signalling. While the role of SOCS2 in down-regulating GH signalling is widely accepted, its role in inhibiting IGF1 action is more speculative, although SOCS2 has been shown to bind to the IGF1 receptor and limit the growth-promoting actions of IGF1 in vivo (Dey et al. 1998, Michaylira et al. 2006). Interestingly, most organs in socs 2 null mice are enlarged, including those in which elevated IGF1 is not detected which possibly indicates that SOCS2 is also required for the regulation of IGF1 signalling itself (Metcalf et al. 2000). Indeed, a role for SOCS2 in regulating both GH and IGF1 signalling in organ-specific contexts is consistent with the observation that socs 2 null mice exhibit characteristics of both GH and IGF1 transgenic mice without entirely recapitulating either phenotype (Metcalf et al. 2000).

In vitro data have further discussed the biological role of SOCS2 in mediating GH action. At low concentrations, SOCS2 inhibits GH signalling (Ram \& Waxman 1999). However, higher concentrations of SOCS2 restore and even stimulate GH signalling, suggesting a further positive modulatory role for SOCS2 in restoring the sensitivity of inhibited $\mathrm{GH}$ signalling in circumstances when it is suppressed by other SOCS proteins (Favre et al. 1999, Greenhalgh et al. 2002). In vivo studies in mice demonstrating that both the absence and overexpression of SOCS2 cause growth enhancement support these in vitro findings (Metcalf et al. 2000, Greenhalgh et al. 2002). It has, therefore, been proposed that SOCS2 regulates growth by exerting a dual effect on GH signalling. Both inactivation and overexpression of SOCS2 result in enhanced $\mathrm{GH}$ signalling and growth, whereas physiological levels of SOCS2 reduce GH signalling. Glucocorticoids, including dexamethasone, are also thought to upregulate SOCS2, desensitise GH signalling and suppress growth (Tollet-Egnell et al. 1999, Rico-Bautista et al. 2006).

A similar phenotype to socs 2 null mice has also been observed in the high growth (hg) mouse, a phenotype that occurs following a spontaneous $500-\mathrm{kb}$ deletion in chromosome 10 of the mouse (Horvat \& Medrano 1995, 1998, 2001). Since the initial discovery of the hg phenotype, the SOCS2 gene has been mapped to the hy chromosomal region possibly explaining the almost identical phenotype: a 30 to $50 \%$ increase in postnatal growth (Horvat \& Medrano 2001). Interestingly, however, unlike the socs 2 null mice, the $h g$ mice have elevated levels of circulating IGF1 which may be due to a deletion of other genes or DNA segments flanking the SOCS2 locus (Horvat \& Medrano 2001).

\section{SOCS3}

Mice lacking SOCS3 expression are embryonically lethal with death occurring at mid-gestation between days 11 and 13 of embryonic development. At this stage, the embryos appear normal but present with a mild growth retardation. The developmental arrest and death were considered to be due to defects in placental development possibly as a result of excess cytokine signalling (Marine et al. 1999, Roberts et al. 2001). 
In comparison to CIS, SOCS1 and SOCS2, preferential induction of SOCS3 mRNA by GH is observed in fibroblasts and hepatocytes. Also constitutive expression of SOCS3 (and SOCS1), but not SOCS2 or CIS resulted in a complete block of GHR-mediated signalling (Adams et al. 1998, Hansen et al. 1999). These data suggest, albeit not in the chondrocytes of the growth plate, that SOCS3 is preferentially stimulated by $\mathrm{GH}$ which results in the complete inhibition of $\mathrm{GH}$ signalling. The implications for this on bone growth are unknown due to the embryonic lethality of the socs 3 null mouse. Knowledge gleaned from studies with articular chondrocytes does, however, suggest that SOCS3 is likely to influence GH/IGF1 signalling in epiphyseal chondrocytes. SOCS3 overexpression of murine articular chondrocytes inhibits IL1-induced STAT1 and STAT3 phosphorylation as well as inhibits IGF1-induced aggrecan expression through antagonising insulin receptor substrate 1 phosphorylation (Smeets et al. 2006).

\section{The SOCS proteins and their effect on bone}

Given that the majority of studies performed have investigated the effects of SOCS1-3, this section has been restricted to the effect of these proteins.

\section{SOCS1}

Mice with homozygous inactivation of the gene encoding the SOCS1 protein die within 21 days of birth with low body weight, fatty degeneration and necrosis of the liver, infiltration of the lung, pancreas, heart and skin by macrophages and granulocytes and a profound depletion of T- and B-lymphocytes (Starr et al. 1998, Metcalf et al. 1999). In the socs 1 null mice, calvarial cells showed distinct phosphorylation of STAT1, but this was hardly detectable in wild-type (WT) mice (Abe et al. 2006). Undercalcified areas in the skulls and sternum, as well as comparatively thinner calcified areas in cortical bone, were found in socs 1 null mice. Mineralisation activity of primary cultured calvarial cells strongly suggested significant impairment in osteoblasts of socs 1 null mice. In situ hybridisation analysis demonstrated that these mice showed a dramatic decrease in the expression level of osteocalcin, a late marker of osteoblast maturation. Osteoclastogenesis stimulation by RANKL is associated with increased expression of IFN- $\beta$ which itself inhibits the differentiation of osteoclasts. However, RANKL simultaneously induces the expression of SOCS1, which can block the signalling of IFN- $\beta$, thus causing a decrease in IFNdependent transcription factor complex (IFN-stimulated gene factor-3) formation (Hayashi et al. 2002). Thus, although the inhibitory cytokines such as type-I IFNs are produced in response to RANKL, the inhibition of osteoclastogenesis may be rescued by inducing the production of signalling suppressors such as SOCS, and this was further confirmed in experiments of SOCS1 overexpression in mouse bone marrow-derived monocytes which conferred resistance to the suppression of osteoclast differentiation by IFN (Ohishi et al. 2005). Consistent with this report, a notable suppression of osteoclast formation and bone destruction induced by lipopolysaccharides have also been reported in socs $1^{+/-}$mice which have a haploinsufficiency of the socs 1 gene (Ohishi et al. 2005).

\section{SOCS2}

Dual energy X-ray absorptiometry analysis of the socs 2 null mouse demonstrated that the areal bone mineral density (aBMD) was reduced in the total tibia. Subregion analyses in the proximal metaphyseal region of the tibia, with a relatively high content of trabecular bone, indicated that the reduced aBMD was due, at least partly, to a reduced trabecular BMD (Lorentzon et al. 2005). Peripheral quantitative computed tomography analyses demonstrated that both the trabecular and cortical volumetric BMD were reduced. The cortical cross-sectional area and cortical thickness were reduced in 4-week-old mice but not in 15 -week-old $\operatorname{socs} 2^{-/-}$mice, suggesting that the main effect on aBMD was a result of reduced trabecular and cortical volumetric BMD, and to a lesser extent due to reduced size of the cortical bone. However, more detailed studies performed recently using micro-computed tomography showed that although cortical and trabecular BMD were similar in the socs 2 null mice and WT mice, the tibiae in 7-week-old socs 2 null mice tibiae were longer, broader and had increased total cross-sectional bone area, increased percent bone volume, trabecular number and trabecular thickness, with associated decreases in trabecular separation (Macrae et al. 2009). The structure model index, which quantifies the characteristic form of a 3D structure in terms of amounts of plates and rods composing the structure (Hildebrand \& Rüegsegger 1997), was also significantly lower in the tibiae from the socs 2 null mice indicating that the trabeculae in socs 2 null mice appeared to be more 'plate-like' and more connected, which is consistent with greater 'strength'. Osteocalcin and TRAP5b, respective markers of bone formation and resorption, were also reported to be higher in the socs 2 null mice. Thus, while the overall BMD may not be significantly altered, a number of microarchitectural markers of bone strength were significantly raised in both the trabecular and cortical compartments of bone in the socs 2 null mouse which is known to have increased growth without systemically raised concentrations of IGF1 (Metcalf et al. 2000). In the C2C12 mesenchymal precursor cell line, stable transfection of SOCS2 potentiated bone morphogenic protein-induced transdifferentiation of $\mathrm{C} 2 \mathrm{C} 12$ cells into osteoblast phenotypes (Ouyang et al. 2006). This effect was observed to be due to regulation of JunB protein synthesis and was independent of the GH signalling pathway (Ouyang et al. 2006). These data suggest that it is possible that $\mathrm{GH}$ dependent and independent pathways may both be responsible for the bone phenotype of the socs 2 null mouse. The bone phenotype of the socs 2 transgenic mice has not yet been described (Greenhalgh et al. 2002). 


\section{SOCS proteins at the crossroads in chronic inflammatory conditions}

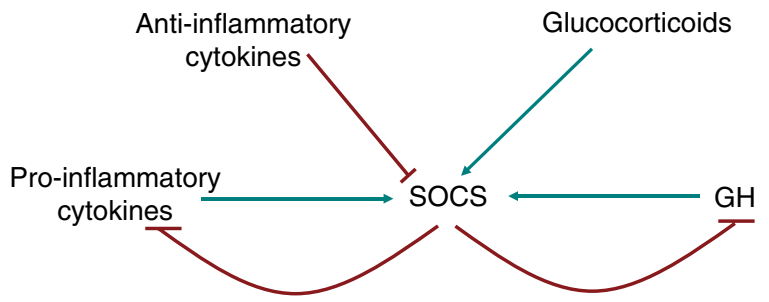

Figure 3 Hypothetical position of SOCS proteins as central modulators of the interaction between cytokines, glucocorticoids and $\mathrm{GH}$. By altering the level of systemic or local SOCS proteins, these factors may induce an effect that alters the overall disease process.

\section{SOCS3}

The socs 3 null phenotype is embryonically lethal, and the effect of this genotype on bone is less clear. In osteoclastogenesis, SOCS3 seems to play a similar role as SOCS1 in dampening the inhibitory action of IFN- $\beta$ on osteoclastogenesis (Hayashi et al. 2002, Lovibond et al. 2003). This inhibitory effect of SOCS3 on IFN- $\beta$ may also be the pathway through which TGF- $\beta$ facilitates osteoclast formation (Fox et al. 2003). In the osteoblast-like osteosarcoma cell line, UMR 106, which expresses a GH-responsive JAK2/STAT5 signalling system, pretreatment with 1,25 dihydroxy-vitamin $\mathrm{D}$ is associated with increased and sustained responsiveness to repeat pulses of $\mathrm{GH}$ stimulation. It seems that this may be due to a reduced $\mathrm{GH}$-induced expression of SOCS3 and CIS (Morales et al. 2002).

\section{Clinical and therapeutic relevance}

Childhood inflammatory bowel diseases, especially those such as Crohn's disease, are commonly complicated by growth retardation and osteoporosis. Pro-inflammatory cytokines are often elevated in such conditions, and improvement of the disease status is often associated with an improvement in growth and skeletal health. Children with chronic inflammatory diseases show elevation of a range of anti- and proinflammatory cytokines (Wong et al. 2008). The systemic GH/IGF1 axis in these children can also show a range of abnormalities (Wong et al. 2010). GH therapy has been used to improve the growth of children with chronic diseases (Wong et al. 2007) and may alter systemic concentration of cytokines (Pagani et al. 2005, Andiran \& Yordam 2007). The SOCS proteins may be central to the underlying pathophysiology of these observed effects (Walters \& Griffiths 2009; Fig. 3) at systemic and local levels, and require further study.

\section{Conclusion}

In conclusion, effective GH signalling, particularly at the level of the target tissue, is vital for optimal linear growth and skeletal development. SOCS proteins are known inhibitors of $\mathrm{GH}$ signalling, but their actions vary from one family member to another and their role may differ depending on the target tissue. There is a need for more translational studies in this field to explore the role of SOCS proteins in mediating the effects of chronic inflammation on linear growth and skeletal development.

\section{Declaration of interest}

The authors declare that there is no conflict of interest that could be perceived as prejudicing the impartiality of the research reported.

\section{Funding}

CF received Institute Strategic Programme Grant funding from the Biotechnology and Biological Sciences Research Council, UK.

\section{References}

Abe T, Nomura S, Nakagawa R, Fujimoto M, Kawase I \& Naka T 2006 Osteoblast differentiation is impaired in SOCS-1-deficient mice. Journal of Bone and Mineral Metabolism 24 283-290. (doi:10.1007/s00774-006-0685-0)

Adams TE, Hansen JA, Starr R, Nicola NA, Hilton DJ \& Billestrup N 1998 Growth hormone preferentially induces the rapid, transient expression of SOCS-3, a novel inhibitor of cytokine receptor signaling. Journal of Biological Chemistry 273 1285-1287. (doi:10.1074/jbc.273.3.1285)

Akeno N, Robins J, Zhang M, Czyzyk-Krzeska MF \& Clemens TL 2002 Induction of vascular endothelial growth factor by IGF-I in osteoblast-like cells is mediated by the PI3K signaling pathway through the hypoxia-inducible factor-2alpha. Endocrinology 143 420-425. (doi:10.1210/en.143.2.420)

Alexander WS, Starr R, Fenner JE, Scott CL, Handman E, Sprigg NS, Corbin JE, Cornish AL, Darwiche R, Owczarek CM et al. 1999 SOCS1 is a critical inhibitor of interferon gamma signaling and prevents the potentially fatal neonatal actions of this cytokine. Cell 98 597-608. (doi:10.1016/S0092-8674(00)80047-1)

Andiran N \& Yordam N 2007 TNF-alpha levels in children with growth hormone deficiency and the effect of long-term growth hormone replacement therapy. Growth Hormone \& IGF Research 17 149-153. (doi:10. 1016/j.ghir.2007.01.002)

Aubin JE, Lian JB \& Stein GS 2006 Bone formation: maturation and functional activities of osteoblast lineage cells. In Primer on the Metabolic Bone Diseases and Disorders of Mineral Metabolism, 6th ed., pp 20-29. Ed. Favus MJ. Washington DC: American Society for Bone and Mineral Research.

Auernhammer CJ, Bousquet C \& Melmed S 1999 Autoregulation of pituitary corticotroph SOCS-3 expression: characterization of the murine SOCS-3 promoter. PNAS 96 6964-6969. (doi:10.1073/pnas.96.12.6964)

Baker J, Liu JP, Robertson EJ \& Efstratiadis A 1993 Role of insulin-like growth factors in embryonic and postnatal growth. Cell 75 73-82. (doi:10. 1016/S0092-8674(05)80085-6)

Ballesteros M, Leung KC, Ross RJ, Iismaa TP \& Ho KK 2000 Distribution and abundance of messenger ribonucleic acid for growth hormone receptor isoforms in human tissues. Journal of Clinical Endocrinology and Metabolism 85 2865-2871. (doi:10.1210/jc.85.8.2865)

Barnard R, Haynes KM, Werther GA \& Waters MJ 1988 The ontogeny of growth hormone receptors in the rabbit tibia. Endocrinology 122 2562-2569. (doi:10.1210/endo-122-6-2562)

Beamer WH \& Eicher EM 1976 Stimulation of growth in the little mouse. Journal of Endocrinology 71 37-45. (doi:10.1677/joe.0.0710037)

Behringer RR, Lewin TM, Quaife CJ, Palmiter RD, Brinster RL \& D'Ercole AJ 1990 Expression of insulin-like growth factor I stimulates normal somatic growth in growth hormone-deficient transgenic mice. Endocrinology 127 1033-1040. (doi:10.1210/endo-127-3-1033) 
Blackburn A, Schmitt A, Schmidt P, Wanke R, Hermanns W, Brem G \& Wolf E 1997 Actions and interactions of growth hormone and insulinlike growth factor-II: body and organ growth of transgenic mice. Transgenic Research 6 213-222. (doi:10.1023/A:1018494108654)

Bougnères P \& Goffin V 2007 The growth hormone receptor in growth. Endocrinology and Metabolism Clinics of North America 36 1-16.

Burch WM, Corda G, Kopchick JJ \& Leung FC 1985 Homologous and heterologous growth hormones fail to stimulate avian cartilage growth in vitro. Journal of Clinical Endocrinology and Metabolism 60 747-750. (doi:10. 1210/jcem-60-4-747)

Canalis E 1980 Effect of insulin-like growth factor I on DNA and protein synthesis in cultured rat calvaria. Journal of Clinical Investigation 66 709-719. (doi:10.1172/JCI109908)

Canalis E, Centrella M, Burch W \& McCarthy TL 1989 Insulin-like growth factor I mediates selective anabolic effects of parathyroid hormone in bone cultures. Journal of Clinical Investigation 83 60-65. (doi:10.1172/JCI113885)

Darnell JE Jr 1997 STATs and gene regulation. Science 277 1630-1635. (doi:10.1126/science.277.5332.1630)

Daughaday WH, Hall K, Raben MS, Salmon WD Jr, van den Brande JL \& van Wyk JJ 1972 Somatomedin: proposed designation for sulphation factor. Nature 235 107. (doi:10.1038/235107a0)

Delany AM, Durant D \& Canalis E 2001 Glucocorticoid suppression of IGF I transcription in osteoblasts. Molecular Endocrinology 15 1781-1789. (doi:10. 1210/me.15.10.1781)

Dey BR, Spence SL, Nissley P \& Furlanetto RW 1998 Interaction of human suppressor of cytokine signaling (SOCS)-2 with the insulin-like growth factor-I receptor. Journal of Biological Chemistry 273 24095-24101. (doi:10. 1074/jbc.273.37.24095)

van der Eerden BC, Karperien M \& Wit JM 2003 Systemic and local regulation of the growth plate. Endocrine Reviews 24 782-801. (doi:10. 1210/er.2002-0033)

Favre H, Benhamou A, Finidori J, Kelly PA \& Edery M 1999 Dual effects of suppressor of cytokine signaling (SOCS-2) on growth hormone signal transduction. FEBS Letters 453 63-66. (doi:10.1016/S00145793(99)00681-X)

Fiorelli G, Formigli L, Zecchi Orlandini S, Gori F, Falchetti A, Morelli A, Tanini A, Benvenuti S \& Brandi ML 1996 Characterization and function of the receptor for IGF-I in human preosteoclastic cells. Bone 18 269-276. (doi:10.1016/8756-3282(95)00485-8)

Fox SW, Haque SJ, Lovibond AC \& Chambers TJ 2003 The possible role of TGF-beta-induced suppressors of cytokine signaling expression in osteoclast/macrophage lineage commitment in vitro. Journal of Immunology 170 3679-3687.

Fuller K, Lean JM, Bayley KE, Wani MR \& Chambers TJ 2000 A role for TGFbeta(1) in osteoclast differentiation and survival. Journal of Cell Science 113 2445-2453.

Gazzerro E \& Canalis E 2006 Bone morphogenetic proteins and their antagonists. Reviews in Endocrine and Metabolic Disorders 7 51-65. (doi:10. 1007/s11154-006-9000-6)

Gevers EF, van der Eerden BC, Karperien M, Raap AK, Robinson IC \& Wit JM 2002 Localization and regulation of the growth hormone receptor and growth hormone-binding protein in the rat growth plate. Journal of Bone and Mineral Research 17 1408-1419. (doi:10.1359/jbmr.2002.17.8.1408)

Goldenberg N \& Barkan A 2007 Factors regulating growth hormone secretion in humans. Endocrinology and Metabolism Clinics of North America 36 37-55. (doi:10.1016/j.ecl.2006.11.003)

Goldshmit Y, Walters CE, Scott HJ, Greenhalgh CJ \& Turnley AM 2004 SOCS2 induces neurite outgrowth by regulation of epidermal growth factor receptor activation. Journal of Biological Chemistry 279 16349-16355. (doi:10.1074/jbc.M312873200)

Green H, Morikawa M \& Nixon T 1985 A dual effector theory of growthhormone action. Differentiation 29 195-198. (doi:10.1111/j.1432-0436. 1985.tb00316.x)

Greenhalgh CJ, Metcalf D, Thaus AL, Corbin JE, Uren R, Morgan PO, Fabri LJ, Zhang JG, Martin HM, Willson TA et al. 2002 Biological evidence that SOCS-2 can act either as an enhancer or suppressor of growth hormone signaling. Journal of Biological Chemistry 277 40181-40184. (doi:10.1074/jbc.C200450200)
Greenhalgh CJ, Rico-Bautista E, Lorentzon M, Thaus AL, Morgan PO, Willson TA, Zervoudakis P, Metcalf D, Street I, Nicola NA et al. 2005 SOCS2 negatively regulates growth hormone action in vitro and in vivo. Journal of Clinical Investigation 115 397-406. (doi:10.1172/JCI22710)

Guicheux J, Heymann D, Rousselle AV, Gouin F, Pilet P, Yamada S \& Daculsi G 1998 Growth hormone stimulatory effects on osteoclastic resorption are partly mediated by insulin-like growth factor I: an in vitro study. Bone 22 25-31. (doi:10.1016/S8756-3282(97)00224-X)

Hansen JA, Lindberg K, Hilton DJ, Nielsen JH \& Billestrup N 1999 Mechanism of inhibition of growth hormone receptor signaling by suppressor of cytokine signaling proteins. Molecular Endocrinology 13 1832-1843. (doi:10.1210/me.13.11.1832)

Hayashi T, Kaneda T, Toyama Y, Kumegawa M \& Hakeda Y 2002 Regulation of receptor activator of NF-kappa B ligand-induced osteoclastogenesis by endogenous interferon-beta (INF-beta) and suppressors of cytokine signaling (SOCS). The possible counteracting role of SOCSs- in IFN-beta-inhibited osteoclast formation. Journal of Biological Chemistry 277 27880-27886. (doi:10.1074/jbc.M203836200)

Herrington J, Smit LS, Schwartz J \& Carter-Su C 2000 The role of STAT proteins in growth hormone signaling. Oncogene 19 2585-2597. (doi:10. 1038/sj.onc.1203526)

Hildebrand T \& Rüegsegger P 1997 Quantification of bone microarchitecture with the structure model index. Computer Methods in Biomechanics and Biomedical Engineering 1 15-23. (doi:10.1080/01495739708936692)

Hilton DJ 1999 Negative regulators of cytokine signal transduction. Cellular and Molecular Life Sciences 55 1568-1577. (doi:10.1007/s000180050396)

Holly J \& Perks C 2006 The role of insulin-like growth factor binding proteins. Neuroendocrinology 83 154-160. (doi:10.1159/000095523)

Horvat S \& Medrano JF 1995 Interval mapping of high growth (hg), a major locus that increases weight gain in mice. Genetics 139 1737-1748.

Horvat S \& Medrano JF 1998 A 500-kb YAC and BAC contig encompassing the high-growth deletion in mouse chromosome 10 and identification of the murine Raidd/Cradd gene in the candidate region. Genomics $\mathbf{5 4}$ 159-164. (doi:10.1006/geno.1998.5540)

Horvat S \& Medrano JF 2001 Lack of Socs2 expression causes the high-growth phenotype in mice. Genomics 72 209-212. (doi:10.1006/geno.2000.6441)

Hou P, Sato T, Hofstetter W \& Foged NT 1997 Identification and characterization of the insulin-like growth factor I receptor in mature rabbit osteoclasts. Journal of Bone and Mineral Research 12 534-540. (doi:10.1359/ jbmr.1997.12.4.534)

Hunziker EB, Wagner J \& Zapf J 1994 Differential effects of insulin-like growth factor I and growth hormone on developmental stages of rat growth plate chondrocytes in vivo. Journal of Clinical Investigation 93 1078-1086. (doi:10.1172/JCI117058)

Ihle JN \& Kerr IM 1995 Jaks and Stats in signaling by the cytokine receptor superfamily. Trends in Genetics 11 69-74. (doi:10.1016/S01689525(00)89000-9)

Isaksson OG, Jansson JO \& Gause IA 1982 Growth hormone stimulates longitudinal bone growth directly. Science 216 1237-1239. (doi:10.1126/ science.7079756)

Isgaard J, Nilsson A, Lindahl A, Jansson JO \& Isaksson OG 1986 Effects of local administration of GH and IGF-1 on longitudinal bone growth in rats. American Journal of Physiology 250 E367-E372.

Jasmin JF, Mercier I, Sotgia F \& Lisanti MP 2006 SOCS proteins and caveolin-1 as negative regulators of endocrine signaling. Trends in Endocrinology and Metabolism 17 150-158. (doi:10.1016/j.tem.2006.03.007)

Kanatani M, Sugimoto T, Nishiyama K \& Chihara K 2000 Stimulatory effect of insulin-like growth factor binding protein- 5 on mouse osteoclast formation and osteoclastic bone-resorbing activity. Journal of Bone and Mineral Research 15 902-910. (doi:10.1359/jbmr.2000.15.5.902)

Kassem M, Brixen K, Blum WF, Mosekilde L \& Eriksen EF 1994 Normal osteoclastic and osteoblastic responses to exogenous growth hormone in patients with postmenopausal spinal osteoporosis. Journal of Bone and Mineral Research 9 1365-1370. (doi:10.1002/jbmr.5650090907)

Klammt J, Pfäffle R, Werner H \& Kiess W 2008 IGF signaling defects as causes of growth failure and IUGR. Trends in Endocrinology and Metabolism 19 197-205. (doi:10.1016/j.tem.2008.03.003) 
Krishnan V, Bryant HU \& Macdougald OA 2006 Regulation of bone mass by Wnt signaling. Journal of Clinical Investigation 116 1202-1209. (doi:10.1172/ JCI28551)

Leaman DW, Leung S, Li X \& Stark GR 1996 Regulation of STAT-dependent pathways by growth factors and cytokines. FASEB Journal 10 1578-1588.

Leong GM, Moverare S, Brce J, Doyle N, Sjögren K, Dahlman-Wright K, Gustafsson JA, Ho KK, Ohlsson C \& Leung KC 2004 Estrogen up-regulates hepatic expression of suppressors of cytokine signaling-2 and -3 in vivo and in vitro. Endocrinology 145 5525-5531. (doi:10.1210/en.2004-0061)

Liu JP, Baker J, Perkins AS, Robertson EJ \& Efstratiadis A 1993 Mice carrying null mutations of the genes encoding insulin-like growth factor I (Igf-1) and type 1 IGF receptor (Igf1r). Cell 75 59-72.

Lorentzon M, Greenhalgh CJ, Mohan S, Alexander WS \& Ohlsson C 2005 Reduced bone mineral density in SOCS-2-deficient mice. Pediatric Research 57 223-226. (doi:10.1203/01.PDR.0000148735.21084.D3)

Lovibond AC, Haque SJ, Chambers TJ \& Fox SW 2003 TGF-beta-induced SOCS3 expression augments TNF-alpha-induced osteoclast formation. Biochemical and Biophysical Research Communications 309 762-767. (doi:10. 1016/j.bbrc.2003.08.068)

Lupu F, Terwilliger JD, Lee K, Segre GV \& Efstratiadis A 2001 Roles of growth hormone and insulin-like growth factor 1 in mouse postnatal growth. Developmental Biology 229 141-162. (doi:10.1006/dbio.2000.9975)

Macrae VE, Horvat S, Pells SC, Dale H, Collinson RS, Pitsillides AA, Ahmed SF \& Farquharson C 2009 Increased bone mass, altered trabecular architecture and modified growth plate organization in the growing skeleton of SOCS2 deficient mice. Journal of Cellular Physiology 218 276-284. (doi:10.1002/jcp.21593)

Madsen K, Friberg U, Roos P, Edén S \& Isaksson O 1983 Growth hormone stimulates the proliferation of cultured chondrocytes from rabbit ear and rat rib growth cartilage. Nature 304 545-547. (doi:10.1038/304545a0)

Makower AM, Wroblewski J \& Pawlowski A 1989 Effects of IGF-I, rGH, FGF, EGF and NCS on DNA-synthesis, cell proliferation and morphology of chondrocytes isolated from rat rib growth cartilage. Cell Biology International Reports 13 259-270. (doi:10.1016/0309-1651(89)90148-3)

Marine JC, McKay C, Wang D, Topham DJ, Parganas E, Nakajima H, Pendeville H, Yasukawa H, Sasaki A, Yoshimura A et al. 1999 SOCS3 is essential in the regulation of fetal liver erythropoiesis. Cell 98 617-627. (doi:10.1016/S0092-8674(00)80049-5)

Mathews LS, Hammer RE, Behringer RR, D’Ercole AJ, Bell GI, Brinster RL \& Palmiter RD 1988a Growth enhancement of transgenic mice expressing human insulin-like growth factor I. Endocrinology 123 2827-2833. (doi:10. 1210/endo-123-6-2827)

Mathews LS, Hammer RE, Brinster RL \& Palmiter RD $1988 b$ Expression of insulin-like growth factor I in transgenic mice with elevated levels of growth hormone is correlated with growth. Endocrinology 123 433-437. (doi:10.1210/endo-123-1-433)

Metcalf D, Alexander WS, Elefanty AG, Nicola NA, Hilton DJ, Starr R, Mifsud S \& Di Rago L 1999 Aberrant hematopoiesis in mice with inactivation of the gene encoding SOCS-1. Leukemia 13 926-934. (doi:10. 1038/sj.leu.2401376)

Metcalf D, Greenhalgh CJ, Viney E, Willson TA, Starr R, Nicola NA, Hilton DJ \& Alexander WS 2000 Gigantism in mice lacking suppressor of cytokine signalling-2. Nature 405 1069-1073. (doi:10.1038/35016611)

Michaylira CZ, Simmons JG, Ramocki NM, Scull BP, McNaughton KK, Fuller CR \& Lund PK 2006 Suppressor of cytokine signaling-2 limits intestinal growth and enterotrophic actions of IGF-I in vivo. American Journal of Physiology. Gastrointestinal and Liver Physiology 291 G472-G481. (doi:10.1152/ajpgi.00218.2005)

Mochizuki H, Hakeda Y, Wakatsuki N, Usui N, Akashi S, Sato T, Tanaka K \& Kumegawa M 1992 Insulin-like growth factor-I supports formation and activation of osteoclasts. Endocrinology 131 1075-1080. (doi:10.1210/ en.131.3.1075)

Morales O, Faulds MH, Lindgren UJ \& Haldosén LA $20021 \alpha, 25-$ dihydroxyvitamin $\mathrm{D}_{3}$ inhibits GH-induced expression of SOCS-3 and CIS and prolongs growth hormone signaling via the Janus kinase (JAK2)/signal transducers and activators of transcription (STAT5) system in osteoblast-like cells. Journal of Biological Chemistry 277 34879-34884. (doi:10.1074/jbc. M204819200)
Mushtaq T, Bijman P, Ahmed SF \& Farquharson C 2004 Insulin-like growth factor-I augments chondrocyte hypertrophy and reverses glucocorticoidmediated growth retardation in fetal mice metatarsal cultures. Endocrinology 145 2478-2486. (doi:10.1210/en.2003-1435)

Nilsson A, Carlsson B, Isgaard J, Isaksson OG \& Rymo L 1990 Regulation by GH of insulin-like growth factor-I mRNA expression in rat epiphyseal growth plate as studied with in-situ hybridization. Journal of Endocrinology 125 67-74. (doi:10.1677/joe.0.1250067)

Nilsson O, Mitchum RD Jr, Schrier L, Ferns SP, Barnes KM, Troendle JF \& Baron J 2005 Growth plate senescence is associated with loss of DNA methylation. Journal of Endocrinology 186 241-249. (doi:10.1677/joe.1.06016)

Ning Y, Schuller AG, Bradshaw S, Rotwein P, Ludwig T, Frystyk J \& Pintar JE 2006 Diminished growth and enhanced glucose metabolism in triple knockout mice containing mutations of insulin-like growth factor binding protein-3, -4, and -5. Molecular Endocrinology 20 2173-2186. (doi:10.1210/ me.2005-0196)

Nishiyama K, Sugimoto T, Kaji H, Kanatani M, Kobayashi T \& Chihara K 1996 Stimulatory effect of growth hormone on bone resorption and osteoclast differentiation. Endocrinology 137 35-41. (doi:10.1210/en.137.1.35)

Ohishi M, Matsumura Y, Aki D, Mashima R, Taniguchi K, Kobayashi T, Kukita T, Iwamoto Y \& Yoshimura A 2005 Suppressors of cytokine signaling-1 and -3 regulate osteoclastogenesis in the presence of inflammatory cytokines. Journal of Immunology 174 3024-3031.

Ouyang X, Fujimoto M, Nakagawa R, Serada S, Tanaka T, Nomura S, Kawase I, Kishimoto T \& Naka T 2006 SOCS-2 interferes with myotube formation and potentiates osteoblast differentiation through upregulation of JunB in C2C12 cells. Journal of Cellular Physiology 207 428-436. (doi:10. $1002 /$ jcp.20579)

Pagani S, Meazza C, Travaglino P, De Benedetti F, Tinelli C \& Bozzola M 2005 Serum cytokine levels in GH-deficient children during substitutive GH therapy. European Journal of Endocrinology 152 207-210. (doi:10.1530/ eje.1.01827)

Parker EA, Hegde A, Buckley M, Barnes KM, Baron J \& Nilsson O 2007 Spatial and temporal regulation of GH-IGF-related gene expression in growth plate cartilage. Journal of Endocrinology 194 31-40. (doi:10.1677/ JOE-07-0012)

Pass C, MacRae VE, Ahmed SF \& Farquharson C 2009 Inflammatory cytokines and the GH/IGF-I axis: novel actions on bone growth. Cell Biochemistry and Function 27 119-127. (doi:10.1002/cbf.1551)

Piessevaux J, Lavens D, Montoye T, Wauman J, Catteeuw D, Vandekerckhove J, Belsham D, Peelman F \& Tavernier J 2006 Functional cross-modulation between SOCS proteins can stimulate cytokine signaling. Journal of Biological Chemistry 281 32953-32966. (doi:10.1074/jbc.M600776200)

Playford MP, Bicknell D, Bodmer WF \& Macaulay VM 2000 Insulin-like growth factor 1 regulates the location, stability, and transcriptional activity of beta-catenin. PNAS 97 12103-12108. (doi:10.1073/pnas.210394297)

Ram PA \& Waxman DJ 1999 SOCS/CIS protein inhibition of growth hormone-stimulated STAT5 signaling by multiple mechanisms. Journal of Biological Chemistry 274 35553-35561. (doi:10.1074/jbc.274.50.35553)

Reinecke M, Schmid AC, Heyberger-Meyer B, Hunziker EB \& Zapf J 2000 Effect of growth hormone and insulin-like growth factor I (IGF-I) on the expression of IGF-I messenger ribonucleic acid and peptide in rat tibial growth plate and articular chondrocytes in vivo. Endocrinology 141 2847-2853. (doi:10. 1210/en.141.8.2847)

Renier G, Clément I, Desfaits AC \& Lambert A 1996 Direct stimulatory effect of insulin-like growth factor-I on monocyte and macrophage tumor necrosis factor-alpha production. Endocrinology 137 4611-4618. (doi:10. 1210/en.137.11.4611)

Rico-Bautista E, Flores-Morales A \& Fernandez-Perez L 2006 Suppressor of cytokine signaling (SOCS) 2, a protein with multiple functions. Cytokine and Growth Factor Reviews 17 431-439. (doi:10.1016/j.cytogfr.2006.09.008)

Roberts AW, Robb L, Rakar S, Hartley L, Cluse L, Nicola NA, Metcalf D, Hilton DJ \& Alexander WS 2001 Placental defects and embryonic lethality in mice lacking suppressor of cytokine signaling 3. PNAS 98 9324-9329. (doi:10.1073/pnas.161271798)

Salmon WD Jr \& Daughday WH 1957 A hormonally controlled serum factor which stimulates sulfate incorporation by cartilage in vitro. Journal of Laboratory and Clinical Medicine 49 825-836. 
Scheven BA \& Hamilton NJ 1991 Longitudinal bone growth in vitro: effects of insulin-like growth factor I and growth hormone. Acta Endocrinologica 124 602-607.

Schlechter NL, Russell SM, Greenberg S, Spencer EM \& Nicoll CS 1986 A direct growth effect of growth hormone in rat hindlimb shown by arterial infusion. American Journal of Physiology 250 E231-E235.

Shinar DM, Endo N, Halperin D, Rodan GA \& Weinreb M 1993 Differential expression of insulin-like growth factor-I (IGF-I) and IGF-II messenger ribonucleic acid in growing rat bone. Endocrinology 132 1158-1167. (doi:10.1210/en.132.3.1158)

Sims NA, Clément-Lacroix P, Da Ponte F, Bouali Y, Binart N, Moriggl R, Goffin V, Coschigano K, Gaillard-Kelly M, Kopchick J et al. 2000 Bone homeostasis in growth hormone receptor-null mice is restored by IGF-I but independent of Stat5. Journal of Clinical Investigation 106 1095-1103. (doi:10.1172/JCI10753)

Sjögren K, Liu JL, Blad K, Skrtic S, Vidal O, Wallenius V, LeRoith D, Törnell J, Isaksson OG, Jansson JO et al. 1999 Liver-derived insulin-like growth factor I (IGF-I) is the principal source of IGF-I in blood but is not required for postnatal body growth in mice. PNAS 96 7088-7092. (doi:10.1073/pnas.96. 12.7088)

Slootweg MC, Most WW, van Beek E, Schot LP, Papapoulos SE \& Löwik CW 1992 Osteoclast formation together with interleukin-6 production in mouse long bones is increased by insulin-like growth factor-I. Journal of Endocrinology 132 433-438. (doi:10.1677/joe.0.1320433)

Smeets RL, Veenbergen S, Arntz OJ, Bennink MB, Joosten LA, van den Berg WB \& van de Loo FA 2006 A novel role for suppressor of cytokine signaling 3 in cartilage destruction via induction of chondrocyte desensitization toward insulin-like growth factor. Arthritis and Rheumatism 54 1518-1528. (doi:10.1002/art.21752)

Starr R, MetcalfD, Elefanty AG, Brysha M, Willson TA, Nicola NA, Hilton DJ \& Alexander WS 1998 Liver degeneration and lymphoid deficiencies in mice lacking suppressor of cytokine signaling-1. PNAS 95 14395-14399. (doi:10. 1073/pnas.95.24.14395)

Stoecklin E, Wissler M, Schaetzle D, Pfitzner E \& Groner B 1999 Interactions in the transcriptional regulation exerted by Stat 5 and by members of the steroid hormone receptor family. Journal of Steroid Biochemistry and Molecular Biology 69 195-204. (doi:10.1016/S0960-0760(99)00052-7)

Stratikopoulos E, Szabolcs M, Dragatsis I, Klinakis A \& Efstratiadis A 2008 The hormonal action of IGF1 in postnatal mouse growth. PNAS 105 19378-19383. (doi:10.1073/pnas.0809223105)

Swolin D \& Ohlsson C 1996 Growth hormone increases interleukin-6 produced by human osteoblast-like cells. Journal of Clinical Endocrinology and Metabolism 81 4329-4333. (doi:10.1210/jc.81.12.4329)

Tollet-Egnell P, Flores-Morales A, Stavreus-Evers A, Sahlin L \& Norstedt G 1999 Growth hormone regulation of SOCS-2, SOCS-3, and CIS messenger ribonucleic acid expression in the rat. Endocrinology 140 3693-3704. (doi:10. 1210/en.140.8.3693)

Trippel SB, Van Wyk JJ \& Mankin HJ 1986 Localization of somatomedin-C binding to bovine growth-plate chondrocytes in situ. Journal of Bone and Joint Surgery. American Volume 68 897-903.

Ueland T 2005 GH/IGF-I and bone resorption in vivo and in vitro. European Journal of Endocrinology 152 327-332. (doi:10.1530/eje.1.01874)

Uronen-Hansson H, Allen ML, Lichtarowicz-Krynska E, Aynsley-Green A, Cole TJ, Höidén-Guthenberg I, Fryklund L \& Klein N 2003 Growth hormone enhances proinflammatory cytokine production by monocytes in whole blood. Growth Hormone \& IGF Research 13 282-286. (doi:10.1016/ S1096-6374(03)00034-0)

Walters TD \& Griffiths AM 2009 Mechanisms of growth impairment in pediatric Crohn's disease. Nature Reviews. Gastroenterology and Hepatology 6 513-523. (doi:10.1038/nrgastro.2009.124)

Wang E, Wang J, Chin E, Zhou J \& Bondy CA 1995 Cellular patterns of insulinlike growth factor system gene expression in murine chondrogenesis and osteogenesis. Endocrinology 136 2741-2751. (doi:10.1210/en.136.6.2741)

Wang J, Zhou J \& Bondy CA 1999 Igf1 promotes longitudinal bone growth by insulin-like actions augmenting chondrocyte hypertrophy. FASEB Journal 13 1985-1990.
Wang J, Zhou J, Cheng CM, Kopchick JJ \& Bondy CA 2004 Evidence supporting dual, IGF I-independent and IGF-I-dependent, roles for GH in promoting longitudinal bone growth. Journal of Endocrinology 180 247-255. (doi:10.1677/joe.0.1800247)

Weedon MN, Lango H, Lindgren CM, Wallace C, Evans DM, Mangino M, Freathy RM, Perry JR, Stevens S, Hall AS et al. 2008 Genome-wide association analysis identifies 20 loci that influence adult height. Nature Genetics 40 575-583. (doi:10.1038/ng.121)

Woelfle J, Chia DJ \& Rotwein P 2003 Mechanisms of growth hormone (GH) action. Identification of conserved Stat5 binding sites that mediate $\mathrm{GH}$-induced insulin-like growth factor-I gene activation. Journal of Biological Chemistry 278 51261-51266. (doi:10.1074/jbc.M309486200)

Won W \& Powell-Braxton L 1998 Insulin-like growth factor gene targeting. In Molecular mechanisms to Regulate the Activities of Insulin-like Growth Factors, pp 57-63. Eds T Katano, N Hizuka \& SI Takahashi. Elsevier: Amsterdam.

Wong SC, Hassan K, McGrogan P, Weaver LT \& Ahmed SF 2007 The effects of recombinant human growth hormone on linear growth in children with Crohn's disease and short stature. Journal of Pediatric Endocrinology and Metabolism 20 1315-1324.

Wong SC, MacRae VE, Gracie JA, McInnes IB, Galea P, Gardner-Medwin J \& Ahmed SF 2008 Inflammatory cytokines in juvenile idiopathic arthritis: effects on physical growth and the insulin-like-growth factor axis. Growth Hormone \& IGF Research 18 369-378. (doi:10.1016/j.ghir.2008.01.006)

Wong SC, Smyth A, McNeill E, Galloway PJ, Hassan K, McGrogan P \& Ahmed SF 2010 The growth hormone-insulin like growth factor 1 axis in children \& adolescents with inflammatory bowel disease $\&$ growth retardation. Clinical Endocrinology 73 220-228. (doi:10.1111/j.1365-2265.2010.03799.x)

Wu Y, Sun H, Yakar S \& LeRoith D 2009 Elevated levels of insulin-like growth factor (IGF)-I in serum rescue the severe growth retardation of IGF-I null mice. Endocrinology 150 4395-4403. (doi:10.1210/en.2009-0272)

Yakar S, Canalis E, Sun H, Mejia W, Kawashima Y, Nasser P, Courtland HW, Williams V, Bouxsein M, Rosen C et al. 2009 Serum IGF-1 determines skeletal strength by regulating subperiosteal expansion and trait interactions. Journal of Bone and Mineral Research 24 1481-1492. (doi:10.1359/jbmr.090226)

Yakar S, Liu JL, Stannard B, Butler A, Accili D, Sauer B \& LeRoith D 1999 Normal growth and development in the absence of hepatic insulin-like growth factor I. PNAS 96 7324-7329. (doi:10.1073/pnas.96.13.7324)

Zezulak KM \& Green H 1986 The generation of insulin-like growth factor-1 - sensitive cells by growth hormone action. Science 233 551-553. (doi:10. 1126/science.3726546)

Zhang CZ, Young WG, Li H, Clayden AM, Garcia-Aragon J \& Waters MJ 1992 Expression of growth hormone receptor by immunocytochemistry in rat molar root formation and alveolar bone remodeling. Calcified Tissue International 50 541-546. (doi:10.1007/BF00582170)

Zhang JG, Farley A, Nicholson SE, Willson TA, Zugaro LM, Simpson RJ, Moritz RL, Cary D, Richardson R, Hausmann G et al. 1999 The conserved SOCS box motif in suppressors of cytokine signaling binds to elongins $\mathrm{B}$ and $\mathrm{C}$ and may couple bound proteins to proteasomal degradation. PNAS 96 2071-2076. (doi:10.1073/pnas.96.5.2071)

Zhang M, Xuan S, Bouxsein ML, von Stechow D, Akeno N, Faugere MC, Malluche H, Zhao G, Rosen CJ, Efstratiadis A et al. 2002 Osteoblastspecific knockout of the insulin-like growth factor (IGF) receptor gene reveals an essential role of IGF signaling in bone matrix mineralization. Journal of Biological Chemistry 277 44005-44012. (doi:10.1074/jbc. M208265200)

Zhao G, Monier-Faugere MC, Langub MC, Geng Z, Nakayama T, Pike JW, Chernausek SD, Rosen CJ, Donahue LR, Malluche HH et al. 2000 Targeted overexpression of insulin-like growth factor I to osteoblasts of transgenic mice: increased trabecular bone volume without increased osteoblast proliferation. Endocrinology 141 2674-2682. (doi:10.1210/en. 141.7.2674)

Received in final form 6 July 2010

Accepted 14 July 2010

Made available online as an Accepted Preprint 14 July 2010 